\title{
Continuity and changes: expanding the Editorial Board
}

\author{
Margaret F. Docker
}

Published online: 17 July 2021

(C) The Author(s), under exclusive licence to Springer Nature B.V. 2021

With great pleasure, we announce a significant expansion of the Editorial Board of Environmental Biology of Fishes. The journal's philosophy has always been to manage changes in "a progressive, evolutionary manner" (Noakes 2003), and we continue this approach. The list of Advisory Editors inside the front cover of this issue reflects the first changes in this regard, with a doubling of the number of dedicated individuals volunteering their time and expertise to serve on the Editorial Board. The existing team of 24 Advisory Editors, several of whom have served in this position for many years, has carried a heavy workload, especially during the past year and a half. The team is now joined by another 26 Advisory Editors to help share the burden and to broaden the expertise and diversity of the Board. These changes reflect our desire to expand the journal's scope to include more articles devoted to cartilaginous fishes and to achieve even greater international and gender representation on the Editorial Board.

\section{Expanded emphasis on cartilaginous fishes}

Sharks, skates, and rays form an immensely popular group of fishes that receive a lot of attention in the

M. F. Docker $(\bowtie)$

Department of Biological Sciences, University

of Manitoba, 50 Sifton Road, Winnipeg, MB R3T 2N2,

Canada

e-mail: Margaret.Docker@umanitoba.ca scientific literature. Environmental Biology of Fishes has always welcomed articles and special issues on the biology of elasmobranchs (e.g., Ebert and Sulikowski 2007; Ebert et al. 2012; Ajemian et al. 2014), and the journal has also published papers on the biology of chimeras (e.g., Di Giácomo et al. 1994; Alarcón et al. 2011). We are now pleased to announce the addition of a number of elasmobranch experts to the Editorial Board to reflect our aim to attract and publish even more articles on the biology of cartilaginous fishes to complement those on the diversity of other marine and freshwater fishes. With the encouragement and guidance of Advisory Editor Peter Klimley, we have expanded the Editorial Board to include a total of 15 Advisory Editors from 10 countries (Australia, Brazil, Canada, China, Ecuador, France, Japan, Mexico, UK, and USA) with expertise related to diverse aspects of elasmobranch biology. With this stellar team of Advisory Editors, we hope to become the leading venue for studies on the environmental biology of cartilaginous fishes.

\section{A more inclusive Editorial Board}

Following in the footsteps of longtime Editor-in-Chief David Noakes, we continue to expand the Editorial Board in an attempt to have the "gatekeepers" of the publication process better reflect the demographics of our international readership and, eventually, the ideal demographics of our discipline (i.e., proactively 
striving for greater gender, geographic, and ethnic diversity rather than merely reflecting current representation in the discipline). By following the adage "many hands make light work," we hope that a more manageable workload will increase the pool of individuals able to take on the role of Advisory Editor, including parents of young children and those already shouldering a disproportionate share of the labor related to EDI (Equity, Diversity, and Inclusion). Although a work in progress, our 50 Advisory Editors now hail from 16 countries and five continents. We also made a conscious effort to include diversity in career stage and language background, and close to $40 \%$ of the Advisory Editors are women. Recognizing that a more inclusive Editorial Board is more likely to attract and appreciate manuscripts on a wider range of research topics and those employing more diverse approaches, we hope that Environmental Biology of Fishes will continue to live up to its reputation as an inclusive and international journal (Noakes 2011).

\section{References}

Ajemian MJ, Neer JA, Noakes D (2014) Special issue: biology and ecology of the durophagous stingrays. Environ Biol Fish 97:965-1081

Alarcón C, Cubillos LA, Acuña E (2011) Length-based growth, maturity and natural mortality of the cockfish Callorhinchus callorhynchus (Linnaeus, 1758) off Coquimbo, Chile. Environ Biol Fish 92:65-78

Di Giácomo E, Parma AM, Orensanz JM (1994) Food consumption by the cock fish, Callorhynchus callorhynchus (Holocephali: Callorhynchidae), from Patagonia (Argentina). Environ Biol Fish 40:199-211

Ebert DA, Sulikowski J (2007) Special issue: biology of skates. Environ Biol Fish 80:107-349

Ebert DA, McElroy WD, White WT (2012) Special issue: feeding ecology of elasmobranchs. Environ Biol Fish 95:1-183

Noakes DLG (2003) Changes and continuity. Environ Biol Fish 66:1-2

Noakes DLG (2011) On the origins. Environ Biol Fish 91:1-5

Publisher's note Springer Nature remains neutral with regard to jurisdictional claims in published maps and institutional affiliations. 